\title{
Practical Methods to Estimate Whole Body Leucine Oxidation in Maple Syrup Urine Disease
}

\author{
LOUIS J. ELSAS, NICOLE P. ELLERINE, AND PETER D. KLEIN
}

Emory University, Department of Pediatrics, Division of Medical Genetics, Atlanta, Georgia 30322 [L.J.E., N.P.E.], and USDA/ARS Children's Nutrition Research Center, Department of Pediatrics, Baylor College of Medicine, Houston, Texas 77030 [P.D.K.]

\begin{abstract}
We report the comparison of noninvasive methods to estimate whole body leucine oxidation in patients who have maple syrup urine disease. We used both an i.v. and an oral bolus of $\mathrm{L}-\left[1-{ }^{13} \mathrm{C}\right]$ leucine and quantitated ${ }^{13} \mathrm{CO}_{2}$ in expired air. Both methods differentiated patients with maple syrup urine disease from heterozygous and control subjects. Eight patients, whose disease differed in clinical severity, were selected for study and had a range of impaired values for whole body leucine oxidation. Six h after an i.v. bolus dose of $\mathrm{L}-\left[11^{13} \mathrm{C}\right]$-L-leucine, ${ }^{13} \mathrm{CO}_{2}$ recoveries ranged from 0.8 to $19.7 \%$. Three of the eight patients had significant increases in ${ }^{13} \mathrm{CO}_{2}$ production after supraphysiologic thiamine therapy. After the oral dose of $\mathrm{L}-[1-$ ${ }^{13}$ Clleucine, homozygous affected children produced less ${ }^{13} \mathrm{CO}_{2}$ than normal, age-matched, childhood controls. In addition, the oxidation of orally administered $L-\left[1-{ }^{13} C\right]$ leucine was reduced significantly in adult heterozygotes compared with adult controls. The proportion of whole body leucine oxidation by affected children was comparatively greater than that by their cultured cells, but cellular oxidation correlated significantly with whole body oxidation of leucine among affected patients. We conclude that these simplified analyses of whole body leucine oxidation define the degree of impaired branched-chain $\alpha$-ketoacid dehydrogenase activity in patients with differing types of maple syrup urine disease and distinguish the subpopulation who might benefit from thiamine supplementation. (Pediatr Res 33: 445-451, 1993)
\end{abstract}

\section{Abbreviations}

MSUD, maple syrup urine disease

WBLO, whole body leucine oxidation

BCKD, branched-chain $\alpha$-ketoacid dehydrogenase

BCAA, branched-chain amino acid

BMR, basal metabolic rate

MSUD is an inborn error of metabolism characterized by a heterogeneous group of mutations, some of which produce structural and functional changes in the multienzyme BCKD (EC 1.2.4.1). The catabolism of BCAA is impaired in homozygous or compound heterozygous patients who have this autosomal recessive disorder. The BCAA include leucine, valine, isoleucine,

Received September 1, 1992; accepted January 12, 1993

Correspondence: Dr. Louis J. Elsas, Emory University, Department of Pediatrics, Division of Medical Genetics, 2040 Ridgewood Dr., Atlanta, GA 30322.

Supported in part by the General Clinical Research Center Public Service Gran to Emory University MO1-RR-00039, by the USDA/ARS Children's Nutrition Research Center under cooperative Agreement 58-7 MN1-6-100, and by Clinical Research Grant No. 6-FY92-0368 from the March of Dimes Birth Defects Foundation. and their respective $\alpha$-ketoacids ( $\alpha$-ketoisocaproate, $\alpha$-ketoisovalerate, and $\alpha$-keto- $\beta$-methylvalerate) ( $1-3)$, which are believed to be toxic to the CNS. The prognosis for newborn infants who have MSUD is directly linked to the degree of impaired BCKD enzyme activity and such confounding variables as irreversible damage conferred on the CNS before a BCAA-restricted diet is implemented (4). The BCKD enzyme complex is made up of four protein subunits (E1 $\alpha, \mathrm{E} 1 \beta, \mathrm{E} 2$, and $\mathrm{E} 3)$, a BCKD-specific kinase, and phosphatase. BCKD is situated in the matrix on the inner mitochondrial membrane $(5,6)$. The E2 subunit forms the core of the complex to which the E1 and E3 are attached (7). Thiamine pyrophosphate is a cofactor that, in the presence of $\mathrm{Mg}^{++}$, forms the binding site for the branched-chain ketoacid substrate on the $\mathrm{E} 1 \alpha$ subunit. The enzyme activity is regulated by a specific kinase and a phosphatase; thus, BCKD activity varies in different tissues. Under normal dietary conditions, most (79\%) of the complex in liver is in the active state, whereas between 30 and $40 \%$ of the total complex in cultured dermal fibroblasts is in the active state (8).

Sensitivity to dietary BCAA is reduced in some MSUD patients after they have ingested pharmacologic doses of thiamine $(5 \mathrm{mg}$. $\left.\mathrm{kg}^{-1} \cdot \mathrm{d}^{-1}\right)$ for a minimum of $3 \mathrm{wk}(9-11)$. Normal leucine tolerance has never returned, however, and the degree of response to thiamine is difficult to assess. Although a mechanism for the response to thiamine has not been confirmed, several hypotheses have been proposed including stabilization of the enzyme complex $(3,12,13)$.

After MSUD is detected by newborn screening techniques, the diagnosis, nutritional management, and prognosis of the patients would be simplified if a clinically useful method were available to estimate BCAA oxidation in vivo. WBLO measurements would determine overall BCKD activity in a population of patients with a heterogeneous continuum of impaired function and include the contribution by differentiated tissues such as liver, muscle, and kidney. These tissues represent most of the total BCKD activity of the organism. Sequential measurements before and during thiamine therapy might also identify the patients in whom pharmacologic doses of thiamine will produce a positive response. We report the development of two breath tests that quantitate the oxidation to ${ }^{13} \mathrm{CO}_{2}$ of a single bolus of $\mathrm{L}-\left[1-{ }^{13} \mathrm{C}\right]$ leucine administered either intravenously or orally. These single bolus methods bypass the relatively invasive techniques of constant infusion and multiple blood testing required of steady state techniques. We compared WBLO among three genotypes: homozygous affected, heterozygotes, and normal controls. We correlated in vivo WBLO with in vitro assays of L-[1$\left.{ }^{14} \mathrm{C}\right]$ leucine decarboxylation by peripheral and cultured cells from the same heterogenous group of patients with MSUD.

\section{MATERIALS AND METHODS}

Study population. Eight children 5 to $9 \mathrm{y}$ of age, previously unreported with MSUD (homozygous affected), were studied, as 
were six of their parents (heterozygote) and seven normal adults (control). Before the study began, the MSUD patients had consumed diets restricted in BCAA and had received at least $180 \%$ of the recommended dietary allowance for thiamine. Individual dietary records were maintained for all patients. Table 1 gives a summary of their clinical status at the time of study, in addition to their calculated leucine intakes and ranges of plasma leucine concentrations. All subjects were studied after an overnight fast. Informed consent was obtained from each subject and his or her parents after a thorough explanation of the purpose of the study, the diet regimen, and the protocol for the kinetic measurements. The study was approved by the Institutional Review Boards for Human Research of Emory University and Baylor College of Medicine, which comply with the World Medical Association Declaration of Helsinki.

Clinical protocol 1: i.v. leucine oxidation. Leucine oxidation was determined in each subject in a fasting, resting state. Baseline breath samples were collected at -15 and $0 \mathrm{~min}$, after which an i.v. bolus of $\mathrm{L}-\left[1-{ }^{13} \mathrm{C}\right]$ leucine $(5 \mathrm{mg} / \mathrm{kg}$ body weight $)$ in sterile saline was administered. Breath samples were collected between 1 and $360 \mathrm{~min}$, as indicated in Figure 1. This clinical protocol was repeated 1 mo after patients, parents, and controls had received pharmacologic amounts of thiamine $\left(5 \mathrm{mg} \cdot \mathrm{kg}^{-1} \cdot \mathrm{d}^{-1}\right)$ p.o.

Clinical protocol 2: oral leucine oxidation. Six of the eight patients volunteered for a reevaluation of WBLO. The protocol required that each patient receive $\mathrm{L}-\left[1-{ }^{13} \mathrm{C}\right]$ leucine orally. Baseline breath samples were collected at -15 and $0 \mathrm{~min}$, after which $\mathrm{L}-\left[1-{ }^{13} \mathrm{C}\right]$ leucine $(5 \mathrm{mg} / \mathrm{kg})$ was ingested and breath samples were collected at $1,5,10,15,20,30,45$, and $60 \mathrm{~min}$ and at halfhourly intervals over the next $6 \mathrm{~h}$. Volunteer, age-matched, homozygous, normal children served as controls for comparisons with the children with MSUD.

Analytical methods. ${ }^{13} \mathrm{CO}_{2}$ abundance was measured by automated gas-isotope-ratio mass spectrometry (14) from 20-mL samples of expired air stored in Vacutainers (Becton Dickinson, Rutherford, $\mathrm{NJ}$ ) and expressed as delta $\%$ versus the limestone standard, Pee Dee Belemnite. $\mathrm{CO}_{2}$ production was calculated as shown in Table 2 using the Schofield equations for BMR (15) and the Weir equation (16) to obtain $\mathrm{CO}_{2}$ production based on an energy expenditure of 1.4 times $B M R$ and a fasting $R Q$ of 0.80 . The standard error of the estimates of $\mathrm{CO}_{2}$ production values for an individual are given by the Schofield equations for BMR: the range is from 6 to $10 \%$ depending upon age. The $\mathrm{CO}_{2}$ production values were combined with the isotopic enrichment data to obtain percent dose recovered at each time point and integrated by trapezoidal methods to obtain the cumulative percent dose recovered. With the quantities of substrate used, the analytical sensitivity of dose recovered was $0.003 \%$.

Enzyme assays. Granulocyte-free, mononuclear white blood cells were prepared from 8 to $10 \mathrm{~mL}$ of heparinized blood in a Ficoll density gradient using modifications of a previously described method (17). Lymphoblasts were transformed from peripheral monocytes using Epstein-Barr viral transformation (18).
Fibroblasts were cultured from biopsied skin in Dulbecco's and Vogt's media using standard methods (19). $1-{ }^{14} \mathrm{C}$-leucine decarboxylation to ${ }^{14} \mathrm{CO}_{2}$ was assayed in the mononuclear cell fraction or monolayer of cells isolated or cultured from the patient and normalized for protein content. To minimize day-to-day assay variation, results in patients' cells were compared with two control cells prepared and assayed under identical conditions on the same day. Results were expressed as percentage of control.

Statistical analyses. The $t$ test was used for analyses among groups of patients and heterozygous and normal control subjects. Linear regression analyses were used to correlate WBLO and cellular oxidation by individuals $(20)$.

\section{RESULTS}

The patients with MSUD and their clinical histories are summarized in Table 1. All patients were between 5 and $9 \mathrm{y}$ of age. They were chosen to represent a spectrum of phenotypic expression and to estimate the continuum of expected impairment. $M R$ and $A R$ are siblings and are on no formal BCAA restriction because symptoms occur only with excessive protein intake. Leucine intake remained constant for each volunteer during all studies conducted at the Clinical Research Facility.

Intravenous breath test. Figure 1 illustrates an exemplary time course for $\mathrm{L}-\left[1-{ }^{13} \mathrm{C}\right]$-leucine oxidation to ${ }^{13} \mathrm{CO}_{2}$ after i.v. bolus infusion in a homozygous affected patient (RD), her heterozygous mother (MM), and a normal adult control (RF). The cumulative percent of the administered $\mathrm{L}-\left[1-{ }^{13} \mathrm{C}\right]-$ leucine oxidized to ${ }^{13} \mathrm{CO}_{2}$ during the $6 \mathrm{~h}$ was $4.2,23.6$, and $20.4 \%$ for the three genotypes, respectively. Thus, the homozygous affected patient was clearly differentiated from the homozygous and heterozygous normal individuals using this i.v. bolus method. Leucine oxidation appeared linear between 0 and $30 \mathrm{~min}$ and was maximal within $60 \mathrm{~min}$ of the bolus infusion; leucine oxidation returned to baseline values at $5 \mathrm{~h}$.

When this i.v. bolus method was compared among the eight homozygous affected children, six heterozygous parents, and seven normal adult controls, the pattern of leucine oxidation among the three genotypes was consistent with that seen in Figure 1, and initial rates could be compared with total leucine oxidation (Fig. 2). The range of ${ }^{13} \mathrm{CO}_{2}$ recovery was broad among patients at both $10 \mathrm{~min}$ and $6.0 \mathrm{~h}$. The percent dose oxidized in 10 min ranged from 0 to $0.04 \%$ with a mean of $0.01 \%$, and at 6 $\mathrm{h}$, from 0.0 to $8.1 \%$ with a mean of $3.9 \%$. These values were clearly different from those of either the homozygous normal controls $(p<0.001)$ or their heterozygous parents $(p<0.001)$. The ranges of leucine oxidation by adult heterozygotes and homozygous normal adult controls overlapped completely. At $10 \mathrm{~min}$, the mean percent dose recovered was $0.1 \%$ and $0.2 \%$, and at $6.0 \mathrm{~h}$, was 19.4 and $20.1 \%$ for heterozygotes and controls, respectively (Fig. 2).

WBLO values of the patients with MSUD (before and during thiamine treatment) were expressed as a percentage of control and correlated to plasma leucine concentration and cellular

Table 1. Clinical characteristics of patients with MSUD*

\begin{tabular}{|c|c|c|c|c|c|c|c|}
\hline $\begin{array}{l}\text { MSUD } \\
\text { patients }\end{array}$ & $\begin{array}{l}\text { Age } \\
(\mathrm{y})\end{array}$ & Sex & $\begin{array}{r}\mathrm{Wt} \\
(\mathrm{kg}) \\
\end{array}$ & $\begin{array}{c}\text { Age at } \\
\text { diagnosis }\end{array}$ & Development & $\begin{array}{c}\text { Calculated } \\
\text { dietary } \\
\text { leucine intake } \\
\left(\mathrm{mg} \cdot \mathrm{kg}^{-1} \cdot \mathrm{d}^{-1}\right)\end{array}$ & $\begin{array}{l}\text { Plasma leucine } \\
\text { range }(\mu \mathrm{M})\end{array}$ \\
\hline $\mathrm{LF}$ & 7 & $\mathrm{~F}$ & 22.0 & $6 \mathrm{~d}$ & $\mathrm{~N}$ & 30 & $107-407$ \\
\hline $\mathrm{AJ}$ & 7 & $\mathrm{~F}$ & 29.2 & $7 \mathrm{~d}$ & Mild MR & 22 & $192-826$ \\
\hline NL & 6 & $\mathrm{~F}$ & 20.2 & $6 \mathrm{~d}$ & $\mathrm{~N}$ & 100 & $102-345$ \\
\hline JS & 9 & $\mathrm{~F}$ & 24.8 & $14 \mathrm{mo}$ & Mild MR & 46 & $355-365$ \\
\hline $\mathrm{RD}$ & 9 & $\mathrm{~F}$ & 26.8 & $2 \mathrm{wk}$ & $\mathrm{N}$ & 38 & $124-231$ \\
\hline MR & 6 & M & 18.5 & 2 wk & $\mathrm{N}$ & 90 & $229-262$ \\
\hline $\mathrm{AR}$ & 5 & $\mathrm{~F}$ & 16.9 & Prenatal & $\mathrm{N}$ & 104 & $284-313$ \\
\hline $\mathrm{BH}$ & 7 & $\mathrm{M}$ & 26.6 & $2 w k$ & Mod MR & 29 & $141-410$ \\
\hline
\end{tabular}

\footnotetext{
*N, normal; MR, mental retardation; Mod, moderate.
} 


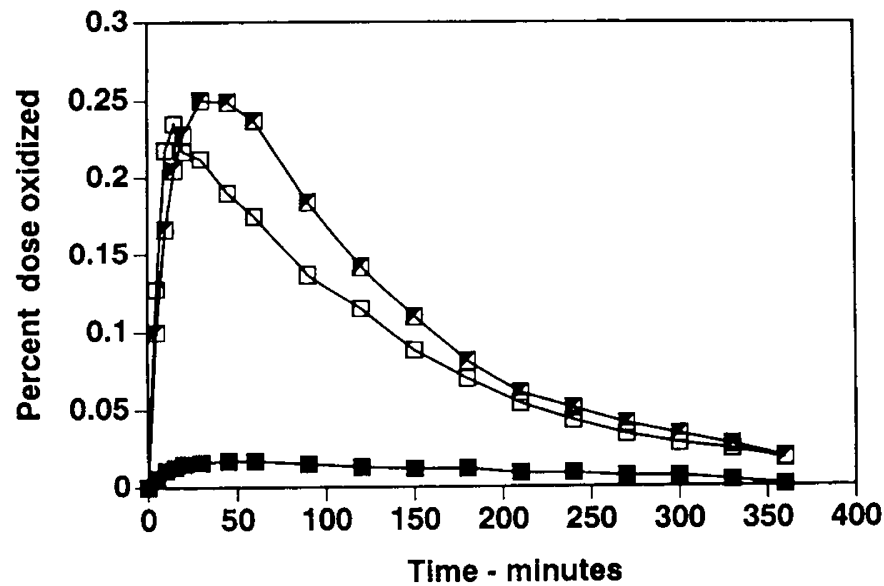

Fig. 1. Time course of leucine oxidation. After an i.v. bolus of L-[1${ }^{13} \mathrm{C}$-leucine $(5 \mathrm{mg} / \mathrm{kg})$, expired ${ }^{13} \mathrm{CO}_{2}$ was quantitated by gas-isotoperatio mass spectrometry at the times indicated. ${ }^{13} \mathrm{CO}_{2}$ data are from duplicate observations and are expressed as percent dose recovered: a homozygous affected patient $(\mathrm{RD}=\mathbf{\square})$, a heterozygote parent $(\mathrm{MM}=$ $\square)$, and a homozygous normal control $(\mathrm{RF}=\square)$ were studied on the same day.

Table 2. Equations used to calculate BMR, energy expenditure, and $\mathrm{CO}_{2}$ production*

\begin{tabular}{|c|c|c|c|}
\hline Age $(y)$ & Sex & Equation & $\begin{array}{c}\text { SE of } \\
\text { estimate } \\
(\%)\end{array}$ \\
\hline \multicolumn{4}{|c|}{ BMR $(\mathrm{MJ} / \mathrm{d})$ by age, sex, weight $(\mathrm{kg})$, and height $(\mathrm{m}) \dagger$} \\
\hline \multirow[t]{2}{*}{$3-10$} & M & $\mathrm{BMR}=0.082 \mathrm{~W}+0.545 \mathrm{H}+1.736$ & 6.78 \\
\hline & & $\mathrm{BMR}=0.071 \mathrm{~W}+0.677 \mathrm{H}+1.553$ & 7.60 \\
\hline \multirow[t]{2}{*}{$10-18$} & & $\mathrm{BMR}=0.068 \mathrm{~W}+0.574 \mathrm{H}+2.157$ & 7.52 \\
\hline & & $\mathrm{BMR}=0.035 \mathrm{~W}+1.948 \mathrm{H}+0.837$ & 9.26 \\
\hline \multirow[t]{2}{*}{$18-30$} & & $\mathrm{BMR}=0.063 \mathrm{~W}-0.042 \mathrm{H}+2.943$ & 9.33 \\
\hline & & $\mathrm{BMR}=0.057 \mathrm{~W}+1.184 \mathrm{H}+0.411$ & 9.33 \\
\hline \multirow[t]{2}{*}{$30-60$} & & $\mathrm{BMR}=0.048 \mathrm{~W}-0.011 \mathrm{H}+3.670$ & 10.37 \\
\hline & & $\mathrm{BMR}=0.034 \mathrm{~W}+0.006 \mathrm{H}+3.530$ & 8.29 \\
\hline \multicolumn{4}{|c|}{ E Expenditure } \\
\hline \multicolumn{4}{|c|}{$\mathrm{EE}=1.4 \cdot \mathrm{BMR} \cdot 239(\mathrm{cal} / \mathrm{MJ})$} \\
\hline \multicolumn{4}{|c|}{$\begin{array}{l}\mathrm{EE}(\mathrm{kcal} / \mathrm{d})=22.4(\mathrm{~L} / \mathrm{mol})\left[1.106 \cdot \dot{\mathrm{V}}_{\mathrm{CO}_{2}}(\mathrm{~mol} / \mathrm{d})+3.91 \cdot \dot{\mathrm{VO}}_{2}\right. \\
\quad(\mathrm{mol} / \mathrm{d})] \ddagger\end{array}$} \\
\hline \multicolumn{4}{|c|}{$\mathrm{RQ}$ in fasting state $\left(\dot{\mathrm{VCO}_{2}} / \dot{\mathrm{V}}_{2}\right)=0.80$} \\
\hline \multicolumn{4}{|c|}{$\mathrm{CO}_{2}$ production } \\
\hline \multicolumn{4}{|c|}{$\mathrm{V}_{\mathrm{CO}_{2}}(\mathrm{~mol} / \mathrm{d})=\mathrm{EE} / 134.25$} \\
\hline \multicolumn{4}{|c|}{$\mathrm{CO}_{2}$ production $\left(\mu \mathrm{M} \cdot \mathrm{kg}^{-1} \cdot \mathrm{min}^{-1}\right)=\left(\dot{\mathrm{V} C O_{2}} \cdot 10^{6}\right) /(24 \mathrm{~h} \cdot 60 \mathrm{~min} \cdot \mathrm{wt})$} \\
\hline
\end{tabular}

$* \mathrm{~W}$, weight; $\mathrm{H}$, height; $\mathrm{EE}$, energy expenditure; $\mathrm{V}_{\mathrm{CO}_{2}}, \mathrm{CO}_{2}$ production; $\dot{\mathrm{V}}_{2}, \mathrm{O}_{2}$ consumption.

$\uparrow$ From Schofield (15).

$\ddagger$ From Weir (16).

leucine oxidation values (Table 3 ). WBLO values of three patients increased during thiamine administration (LF, AJ, and NL). Thiamine therapy also decreased plasma leucine concentrations when the dietary leucine intakes of the subjects were identical. WBLO and plasma leucine concentrations in the other five patients (RD, JS, MR, BH, and AR; Table 3) and all controls (not shown) showed no response to thiamine (Table 3). This correlation of WBLO to plasma leucine concentrations was expected, because changes in leucine pool size should have an inverse effect on leucine oxidation rates. One patient $(\mathrm{BH})$ did not respond to thiamine therapy and oxidized $6.2 \%$ of leucine to $\mathrm{CO}_{2}$ on his basal study but oxidized $0 \%$ while taking thiamine. Because it was necessary to restrict his dietary leucine intake to $21 \mathrm{mg} \cdot \mathrm{kg}^{-1} \cdot \mathrm{d}^{-1}$ (Table 1 ) and his peripheral lymphocytes, trans-
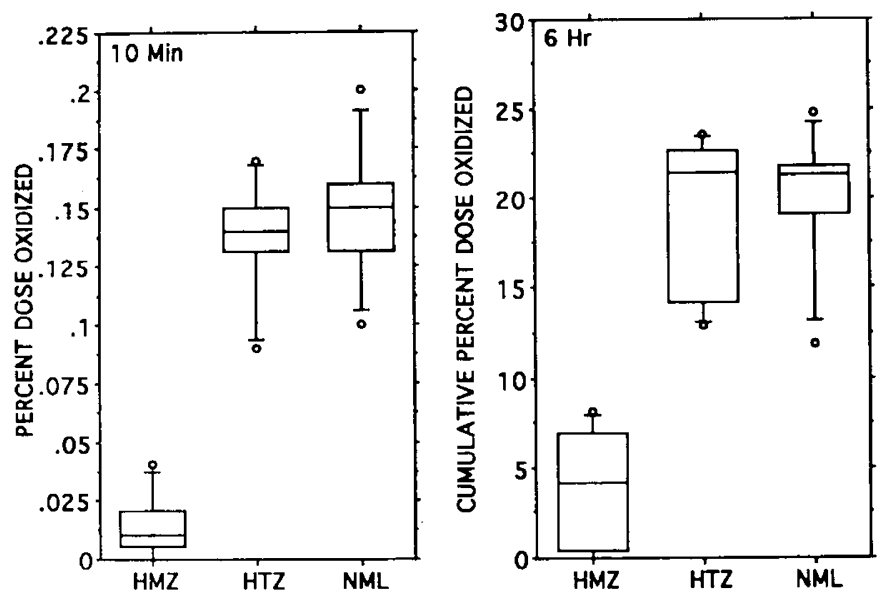

Fig. 2. Whole body L- $\left[1{ }^{13} \mathrm{C}\right]-$ leucine oxidation to ${ }^{13} \mathrm{CO}_{2}$. The recovery of $\mathrm{L}-\left[1-{ }^{13} \mathrm{C}\right]$-leucine administered by i.v. bolus infusion as ${ }^{13} \mathrm{CO}_{2}$ in breath from eight homozygous affected patients $(H M Z)$, six heterozygous parents $(H T Z)$, and seven homozygous normal controls $(N M L)$ is shown as percent dose recovered and as cumulative percent dose recovered at $10 \mathrm{~min}$ upon completion of the study at $6 \mathrm{~h}$. Box whisker plot indicates mean $\pm \mathrm{SD}$ as a vertical rectangle, median value as a cross bar, $95 \%$ confidence limits as vertical bars, and outlier points as circles.

formed lymphoblasts, and cultured fibroblasts oxidized leucine at only 0.9 to $2 \%$ of controls (Table 3 ), his basal value was probably spurious.

During the time that patients received thiamine, their WBLO values after a bolus injection of $\mathrm{L}-\left[1-{ }^{13} \mathrm{C}\right]$ leucine correlated with their values for cellular $\mathrm{L}-\left[1-{ }^{14} \mathrm{C}\right]$ leucine oxidation (Table 3 ). On the basis of simple regression analyses, WBLO correlated best with lymphoblast BCKD activity $(r=0.885, p=0.008)$, second best with fresh peripheral lymphocytes $(r=0.801 ; p=0.03)$, and least with cultured dermal fibroblasts $(r=0.697, p=0.08)$. The addition of thiamine $(100 \mathrm{mg} / \mathrm{L})$ to the culture medium did not affect $\mathrm{BCKD}$ whether or not patients were "thiamine responsive" (data not shown). This finding further supported the need for an in vivo method with which to compare leucine oxidation in patients both off and on high-dose thiamine therapy.

The percentage of overall leucine oxidation was relatively high in the patients compared with the percentage in their cultured cells (Table 3). The range in percentage of control for WBLO by all eight patients on thiamine therapy was 0.0 to $40.0 \%$, whereas their lymphoblast oxidation values ranged from 2.0 to $24.0 \%$ of control values. Individual patient WBLO values were greater than his or her cellular oxidation values, suggesting the presence of more residual leucine decarboxylation activity in differentiated organs, such as liver, muscle, and kidney, than in their individual cellular preparations.

Oral breath test. The percent dose oxidized over the $6 \mathrm{~h}$ differentiated the homozygous affected patient (RD), her heterozygous mother (MM), and a normal adult control (RF) (Fig. 3 ). By comparing leucine oxidation rates after i.v. administration with those after oral administration, several differences in the time courses among the genotypes were apparent (Fig. 1 versus Fig. 3). This affected child was discriminated on the basis of early time points (10 min after i.v. administration), whereas ${ }^{13} \mathrm{CO}_{2}$ appearance in breath after oral administration was influenced by intestinal absorption with a greater variation in the time required to reach peak values. These differences were consistent within genotypes and suggested a secondary effect on intestinal leucine transport. After oral leucine administration, values for the normal control showed prompt absorption and oxidation of ingested leucine, whereas the heterozygous parent showed a delayed and broadened peak of oxidation (Fig. 3). This time course appeared to exaggerate the results by the i.v. methods (Fig. 1). The homozygous affected patients produced very little ${ }^{13} \mathrm{CO}_{2}$ before 240 
ELSAS ET AL

Table 3. Comparison of WBLO and cellular oxidation in eight homozygous deficient MSUD patients before (-) and during (+) thiamine therapy

\begin{tabular}{|c|c|c|c|c|c|c|c|c|c|}
\hline \multirow[b]{2}{*}{ Patient } & \multicolumn{2}{|c|}{ WBLO cum \% dose* } & \multicolumn{2}{|c|}{$\begin{array}{l}\text { WBLO as } \\
\% \text { control }\end{array}$} & \multicolumn{2}{|c|}{$\begin{array}{l}\text { Plasma } \\
\text { leucine } \\
(\mu \mathrm{M}) \dagger\end{array}$} & \multicolumn{3}{|c|}{$\begin{array}{l}\text { Cellular oxidation of } 1-{ }^{14} \mathrm{C} \text {-leucine } \\
\qquad(\% \text { control }) \ddagger\end{array}$} \\
\hline & - & + & - & + & - & + & Fibroblast & Lymphoblast & Lymphocyte \\
\hline \multicolumn{10}{|l|}{ Thiamine responsive } \\
\hline $\mathrm{LF}$ & 0.0 & 3.6 & 0.0 & 17.0 & 1161 & 378 & 10.0 & 4.4 & 2.3 \\
\hline $\mathrm{AJ}$ & 0.0 & 1.3 & 0.0 & 6.0 & 1718 & 826 & 2.0 & 2.7 & 0.0 \\
\hline $\mathrm{NL}$ & 0.7 & 1.9 & 3.0 & 8.1 & 337 & 102 & 5.3 & 2.0 & 1.7 \\
\hline \multicolumn{10}{|l|}{ Thiamine nonresponsive } \\
\hline JS & 3.6 & 1.7 & 17.0 & 8.0 & 355 & 365 & 7.0 & 7.2 & 10.0 \\
\hline RD & 4.7 & 4.2 & 23.0 & 20.0 & 399 & 231 & 2.2 & NA§ & 2.3 \\
\hline $\mathrm{BH}$ & 6.2 & 0.0 & 30.1 & 0.0 & 141 & 142 & 0.9 & 2.0 & 0.9 \\
\hline MR & 8.1 & 7.3 & 40.0 & 34.4 & 262 & 229 & 19.0 & 24.0 & 23.0 \\
\hline $\mathrm{AR}$ & 7.7 & 8.4 & 38.0 & 39.1 & 313 & 284 & NA & 17.7 & NA \\
\hline Adult controls $(n=7)$ & $20.1 \pm 4.1$ & $21.1 \pm 5.1$ & & & & & & & \\
\hline
\end{tabular}

* Cumulative dose oxidized at $360 \mathrm{~min}$.

$\dagger$ Plasma leucine concentration at initiation ( 0 min) of WBLO study.

$\ddagger$ Leucine concentration was $1000 \mu \mathrm{M}$ in all studies.

$\S \mathrm{NA}$, not available.

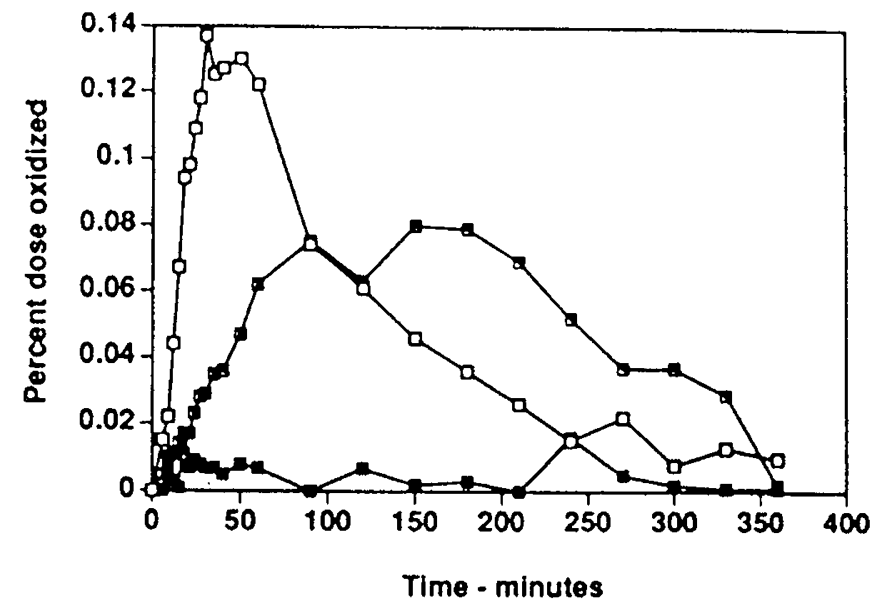

Fig. 3. Time course of leucine oxidation after administration of oral $\mathrm{L}-\left[1-{ }^{13} \mathrm{C}\right]$-leucine. The original triad, homozygous affected patient (RD $=\square)$, heterozygous parent $(M M=\mathbf{V})$, and homozygous normal control $(\mathrm{RF}=\square)$, were studied simultaneously, and the absolute percent dose oxidized is expressed at each time point over $360 \mathrm{~min}$ after stable isotope ingestion. Each point represents duplicate samples at the same breath collection.

min, but label appeared in breath after this time. This delayed appearance of ${ }^{13} \mathrm{CO}_{2}$ in affected patients may have resulted from utilization of leucine by intestinal flora. The affected child was easily differentiated from age-matched controls at 60 min after substrate ingestion (Figs. 4 and 5).

When breath test curves for the homozygous affected patients and age-matched controls were compared, the patients excreted less ${ }^{13} \mathrm{CO}_{2}$ between 60 and 90 min after $\mathrm{L}-\left[1-{ }^{13} \mathrm{C}\right]$ leucine ingestion than controls (Figs. 4 and 5). Because of increased ${ }^{13} \mathrm{CO}_{2}$ production between 240 and 360 min by affected patients, these latter time points were less discriminating with oral methods (Figs. 4 and 5). Because of the delay in the onset of $L-\left[1-{ }^{13} \mathrm{C}\right]$ leucine oxidation in homozygous affected patients, the interval at which ${ }^{13} \mathrm{CO}_{2}$ measurements were most discriminating was between 60 and $90 \mathrm{~min}$ rather than either the 10 - or $30-\mathrm{min}$ time points used in the i.v. protocol.

Statistical evaluation of the time points at 60,90 , and $240 \mathrm{~min}$ is shown in Figure 5 in which the cumulative percent doses recovered as ${ }^{13} \mathrm{CO}_{2}$ in breath from the six patients and seven age-

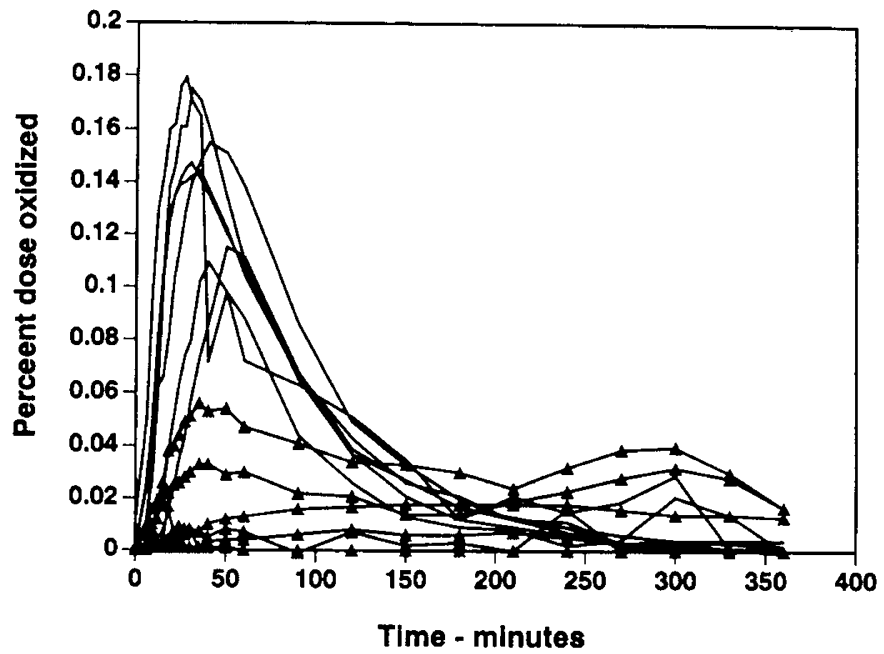

Fig. 4. The time course of ${ }^{13} \mathrm{CO}_{2}$ recovery after oral L- $\left[1-{ }^{13} \mathrm{C}\right]$-leucine administration. Seven controls (solid lines) aged 5-9 y were compared with six homozygous affected patients (lines with symbols) of similar age.

matched controls were compared. There were no overlapping values at any of these time points, and clinically affected children, including five "variant" patients, were statistically different from unaffected control children $(p<0.001)$. These integral values showed that homozygous affected children had a mean WBLO value of $3.8 \pm 3.1 \%$ compared with $12.3 \pm 2.3 \%$ for controls $(p$ $<0.001$ ). In addition, the percent dose excreted as ${ }^{13} \mathrm{CO}_{2}$ at 60 or $90 \mathrm{~min}$ after leucine was administered could be used as a discriminant function for impaired BCKD.

One unexpected finding was that the oral breath test differentiated adult obligate heterozygotes from homozygous normal controls (Table 4). These differences were most striking in the cumulative percent dose values at the 60 - and 90 -min time points of analysis $(p<0.001$ by $t$ test).

\section{DISCUSSION}

Stable isotopes have been used by other investigators to establish WBLO and steady state analyses of protein turnover in patients with MSUD (21-25). These studies gave conflicting 


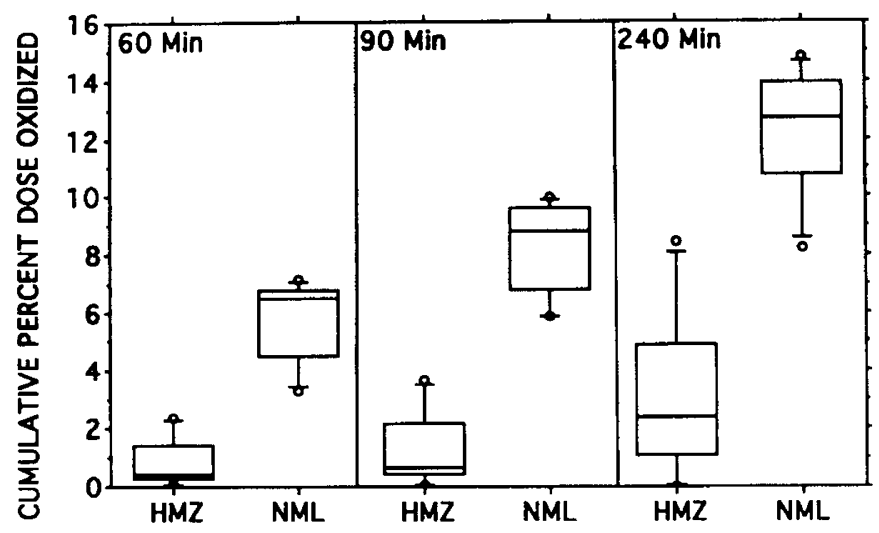

Fig. 5. Box whisker plot for cumulative percent dose oxidized after oral ingestion of ${ }^{13} \mathrm{C}$-leucine by six homozygous deficient $(H M Z)$ children and seven age-matched normal controls (NML) at 60, 90, and $240 \mathrm{~min}$. All differences had values of $p<0.01$.

Table 4. Production of ${ }^{13} \mathrm{CO}_{2}$ by adult heterozygotes and controls after ingestion of $L-\left[1-{ }^{13} C\right] l$ leucine

\begin{tabular}{|c|c|c|c|}
\hline \multirow[b]{2}{*}{ Subject } & \multicolumn{3}{|c|}{ Percent cumulative dose oxidized } \\
\hline & $60 \mathrm{~min}$ & $90 \mathrm{~min}$ & $4 \mathrm{~h}$ \\
\hline \multicolumn{4}{|c|}{ Adult heterozygotes } \\
\hline MM & 1.40 & 3.09 & 11.82 \\
\hline MK & 1.90 & 4.53 & 11.99 \\
\hline SK & 5.20 & 7.56 & 12.75 \\
\hline $\mathrm{FF}$ & 1.38 & 3.77 & 11.22 \\
\hline LT & 2.61 & 4.42 & 7.77 \\
\hline $\mathrm{AR}$ & 3.19 & 5.40 & 11.72 \\
\hline Mean & 2.61 & 4.79 & 11.21 \\
\hline $\mathrm{SD}$ & 1.46 & 1.58 & 1.76 \\
\hline \multicolumn{4}{|l|}{ Adult controls } \\
\hline SM & 4.61 & 7.37 & 14.78 \\
\hline LG & 4.44 & 6.54 & 10.84 \\
\hline $\mathrm{RR}$ & 7.59 & 9.35 & 16.70 \\
\hline $\mathrm{FF}$ & 6.37 & 8.10 & 14.07 \\
\hline SL & 5.12 & 7.81 & 12.42 \\
\hline FD & 7.28 & 10.43 & 18.44 \\
\hline $\mathrm{ZXF}$ & 4.89 & 7.50 & 13.52 \\
\hline JW & 5.67 & 8.22 & 14.40 \\
\hline FW & 4.86 & 7.48 & 14.40 \\
\hline Mean & 5.84 & 8.06 & 14.40 \\
\hline $\mathrm{SD}$ & 1.14 & 1.17 & 2.21 \\
\hline$t$ value & 4.3706 & 4.6485 & 2.9466 \\
\hline Two-tailed $p$ & 0.0008 & 0.0005 & 0.0113 \\
\hline
\end{tabular}

information about the amount of $\mathrm{L}-\left[1-{ }^{13} \mathrm{C}\right]$ leucine oxidized to ${ }^{13} \mathrm{CO}_{2}$ by different patients. Collins et al. (21), for example, found that children who had MSUD oxidized 25 to $50 \%$ leucine compared with adult controls, whereas Thompson et al. $(22,23)$ found little or no enrichment of breath ${ }^{13} \mathrm{CO}_{2}$ after primed constant infusions of leucine. Although WBLO was not compared with cellular leucine oxidation in either study, different mutations of genes for the BCKD and different degrees of impaired enzyme functions were probably responsible for these differences in WBLO. Previous studies of leucine turnover kinetics have used a protocol requiring a primed-constant infusion of leucine as well as a second isotopically labeled amino acid, multiple blood and breath samples from indwelling catheters, and a second day of $\mathrm{NaH}^{13} \mathrm{CO}_{3}$ retention analysis for normalization of ${ }^{13} \mathrm{CO}_{2}$ recovery. Understandably (22-25), it has been difficult to recruit children as controls or to repeat studies in the same patient.

We present simpler methods to measure $\mathrm{L}-\left[1-{ }^{13} \mathrm{C}\right]$-leucine ox- idation to ${ }^{13} \mathrm{CO}_{2}$ using a single bolus of leucine $(5 \mathrm{mg} / \mathrm{kg})$ administered either by injection or ingestion without blood sampling. This simplified approach, using only measurement of ${ }^{13} \mathrm{CO}_{2}$ in expired air, does not provide detailed kinetic analysis of leucine metabolism or protein turnover rates. In addition, leucine pools will affect oxidation rates; this is an anticipated and desirable relationship for studies in which the diagnosis and management of patients with impaired leucine oxidation are to be studied. Our data indicate that bolus studies are clinically useful for identifying the degree of BCKD impairment in individual patients. Because multiple venipunctures and i.v. infusions were not required, parents and children volunteered for not only the original test but also for subsequent repeats of these tests. Thus, we could compare WBLO among patients with MSUD before and during thiamine therapy, recruit children as volunteer controls, and compare oral and i.v. methods in the same individual. Several observations support the contention that these simplified methods measured WBLO. First, within 5 $\mathrm{h}$ after a single i.v. bolus of $\mathrm{L}-\left[1-{ }^{13} \mathrm{C}\right]$ leucine, the enrichment of ${ }^{13} \mathrm{CO}_{2}$ in breath had returned to basal levels. Second, although all patients listed in Table 1 had been identified clinically or by biochemical screening for elevated blood leucine concentrations, a wide range of clinical disease and nutritional control was observed. Thus, we anticipated heterogeneity of impaired $\mathrm{BCKD}$ activity that was reflected in each patient's whole body and cellular leucine oxidation values. Furthermore, WBLO values were correlated with the patient's cellular leucine oxidation values (Table 3). Third, of the three genotypes studied using either i.v. or oral bolus techniques, patients with clinically impaired BCKD were clearly different from obligate heterozygotes or controls who were homozygous for the normal alleles. Fourth, unaffected heterozygotes with normal plasma leucine concentrations had less leucine oxidation than controls (Table 3), supporting the contention that these ${ }^{13} \mathrm{CO}_{2}$ breath tests primarily measure leucine oxidation through the BCKD pathway. It should be realized, however, that the six obligate heterozygous individuals studied were parents of patients with severe BCKD impairment. We are presently attempting to determine whether heterozygous individuals who have less severe mutant alleles can be detected by these oral leucine oxidation studies.

Thiamine responsiveness in patients with MSUD can be estimated by a variety of methods, but all are complex or difficult to standardize $(3,9,10-13,26-29)$. Several theories were generated from studies of cellular fractions from patients $(3,30,31)$, but testing these hypotheses in vivo necessitates that patients undergo weeks of hospitalization in a clinical research unit to enable standard balance studies (13). Using the methods described in the present study, a clinical response to as few as $3 \mathrm{wk}$ of thiamine therapy $(5 \mathrm{mg} / \mathrm{kg})$ was confirmed or denied by increased oxidation of $\mathrm{L}-\left[1-{ }^{13} \mathrm{C}\right]$ leucine in a single day (Table 3 ). While two patients (LF and $\mathrm{AJ}$ ) were receiving supraphysiologic doses of thiamine, their WBLO levels were readily measurable at 17.0 and $6.0 \%$, respectively, of controls. When thiamine was removed from their diets, which were otherwise constant in BCAA content, these patients became ataxic and developed high plasma leucine concentrations and their WBLO levels dropped to zero. Thiamine responsiveness was not directly related to residual enzyme activity, as seen in siblings $A R$ and $M R$, who had an "intermittent" form of MSUD with relatively high residual BCKD but demonstrated no increase in WBLO on thiamine therapy. Their results also exemplified the reproducibility of our methodology. The results of leucine oxidation studies (1 mo apart) were similar: 40.0 and $34.0 \%$ of control for MR and 38.0 and $39.1 \%$ of control for AR before and during thiamine administration, respectively (Table 3). Although these parameters do not explain the mechanism by which patients respond to thiamine, they do enable a more precise clinical definition of the type of MSUD in a given patient and his or her thiamine responsiveness.

Of the two methods of bolus administration (i.v. and oral), the 
oral test involves only the ingestion of a few teaspoons of a tasteless solution and the collection of a few breath samples at timed intervals and would enable field studies in children. The oral breath test reflected a number of variables in addition to WBLO, such as gastric emptying, enteral absorption, and the possibility of leucine utilization by intestinal flora. These responses were reflected in the control subjects by the slower rise and broader peak of maximum oxidation after oral administration of leucine compared with i.v. injection. Of particular interest was the late peak of ${ }^{13} \mathrm{CO}_{2}$ that appeared in MSUD patients. This peak probably reflected the capacity of intestinal flora to oxidize $\mathrm{L}-\left[1-{ }^{13} \mathrm{C}\right]$ leucine to ${ }^{13} \mathrm{CO}_{2}$ rather than endogenous oxidation. This late peak was not present in the control children or in the patients when they received the leucine by i.v. administration. Despite these differences, the percent dose oxidized at 60,90 , and 240 min after leucine ingestion clearly differentiated the heterogeneous group of MSUD patients from childhood controls (Fig. 5). Of considerable interest was the fact that the mean value for oxidation of oral leucine by heterozygotes was significantly different from that of the adult homozygous normal controls (Table 4). The fasting plasma leucine concentrations in all heterozygous and homozygous normal controls were in the normal biologic range. The heterozygous individual, $A R$, was the parent of NL, and parents of LF, AF, FS, RD, and $\mathrm{BH}$ were the other five heterozygous persons studied. Parents of the "intermediate" MSUD patients, MR and AR, were not available for study. Although leucine intake could affect leucine transport by the jejunum (24), preliminary diet histories do not indicate that parents and controls had different protein or leucine intakes. Thus, this finding probably reflects real differences in endogenous hepatic oxidation of leucine by heterozygotes for impaired $\mathrm{BCKD}$ and supports the contention that these non-steady state leucine oxidation methods measure the BCKD pathway.

We have thus established that leucine breath tests of WBLO have a relatively broad range of applicability and can be used to identify clinically significant BCKD deficiencies. These noninvasive, simple methods will enable an increase in epidemiologic assessments of the heterogeneous group of patients with impaired BCKD and identification of thiamine-responsive patients, and perhaps the oral breath test will enable the identification of heterozygotes. These tests can also be used in conjunction with molecular advances in understanding and treating MSUD.

At the molecular level, the cDNA for four of the enzymes producing the multienzyme BCKD complex have been cloned (32-35). The E2 cDNA has produced stably transfected fibroblasts from an E2- MSUD patient and could be placed in retroviral vectors suitable for hepatic or muscle cell transfection and autologous transplantation (36). Measurement of WBLO will be useful in recurrent evaluation of the efficiency and stability of gene transfer into individual patients with MSUD when this form of therapy becomes available (37).

Acknowledgments. The authors thank Paul Fernhoff, M.D., Rani Singh, Ph.D., and Barbara Kruse, R.D., M.P.H., for helping with patient care and diet; Sara Sekely, M.S., for ${ }^{13} \mathrm{C}$ isotope analysis; and Dean J. Danner, Ph.D., and Nicola Longo, M.D., Ph.D., for reading the manuscript.

\section{REFERENCES}

1. Menkes JH, Hurst PL, Craig JM 1954 A new syndrome: progressive familial infantile cerebral dysfunction associated with an unusual urinary substance. Pediatrics 14:462-467

2. Danner DJ, Armstrong N, Heffelfinger SC, Sewell ET, Priest JH, Elsas LJ 1985 Absence of branched chain acyl-transferase as a cause of maple syrup urine disease. J Clin Invest 75:858-860

3. Danner DJ, Elsas LJ 1989 Disorders of branched-chain amino acids and keto acid metabolism. In: Scriver C, Beaudet A, Sly W, Valle D (eds) The Metabolic Basis of Inherited Disease. Vol 1, 6th Ed. McGraw-Hill, New York, pp 671-692

4. Westall RG 1967 Dietary treatment of maple syrup urine disease. Am J Dis
Child 113:58-59

5. Heffelfinger SC, Sewell ET, Danner DJ 1983 Identification of specific subunits of highly purified bovine liver branched chain $\alpha$-ketoacid dehydrogenase. Biochemistry 22:5519-5522

6. Danner DJ, Lemmon SK, Besharse JC, Elsas LJ 1979 Purification and characterization of branched chain $\alpha$ ketoacid dehydrogenase from bovine liver mitochondria. J Biol Chem 254:5522-5526

7. Reed LJ, Hackert ML 1990 Structure-function relationships in dihydrolipoamide acyltransferases. J Biol Chem 265:8971-8974

8. Wagenmakers AJM, Schepens JTG, Veldhuizen JAM, Veerkamp JH 1984 The activity state of the branched chain 2-oxo acid dehydrogenase complex in rat tissues. Biochem J 220:273-281

9. Elsas LJ, Danner DJ 1982 The role of thiamine in maple syrup urine disease. Ann NY Acad Sci 378:404-421

10. Danner DJ, Davidson ED, Elsas LJ 1975 Thiamine increases the specific activity of human liver branched chain $\alpha$-ketoacid dehydrogenase. Nature 254:529-530

11. Fernhoff PM, Lubitz D, Danner DJ, Dembure PP, Schwartz HP, Hillman R, Bier DM, Elsas LJ 1985 Thiamine response in maple syrup urine disease. Pediatr Res 19:1011-1016

12. Heffelfinger SC, Sewell ET, Elsas LJ, Danner DJ 1984 Direct physical evidence for stabilization of branched-chain $\alpha$-ketoacid dehyrogenase by thiamin pyrophosphate. Am J Hum Genet 36:802-807

13. Danner DJ, Lemmon SK, Elsas LJ 1980 Stabilization of mammalian liver branched chain $\alpha$-ketoacid dehydrogenase by thiamin pyrophosphate. Arch Biochem Biophys 202:23-28

14. Schoeller DA, Klein PD 1979 A microprocessor controlled mass spectrometer for the fully automated purification and isotopic analysis of breath carbon dioxide. Biomed Mass Spectrom 6:350-355

15. Schofield WN 1985 Predicting basal metabolic rate, new standards and review of previous work. Hum Nutr Clin Nutr 39C(suppl 1):5-41

16. deV Weir JB 1949 New methods for calculating metabolic rate with special reference to protein metabolism. J Physiol 109:1-9

17. Wendel U, Wohler W, Goedde HW, Langenbeck U, Passarge E, Rudiger HW 1973 Rapid diagnosis of maple syrup urine disease (branched chain ketoaciduria) by microenzyme assay in leukocytes and fibroblasts. Clin Chem Acta 4:433-440

18. Neitzel H 1986 A routine method for the establishment of permanent growing lymphoblastoid cell lines. Hum Genet 173:320-326

19. Elsas LJ, Pask BA, Wheeler FB, Perl DP, Trusler S 1972 Classical maple syrup urine disease: cofactor resistance. Metabolism 12:929-944

20. Moore DS 1985 Statistics: Concepts and Controversies, 2nd Ed. Freeman WH and Company, Philadelphia

21. Collins JE, Umpleby AM, Boroujerdi MA, Leonard JV, Sonksen PH 1987 Effect of insulin on leucine kinetics in maple syrup urine disease. Pediatr Res 21:10-13

22. Thompson GN, Bresson JL, Pacy PT, Bonnefont JP, Walter JH, Leonard JV, Saudubray JM, Halliday D 1990 Protein and leucine metabolism in maple syrup urine disease. Am J Physiol 258:E654-E660

23. Thompson GN, Walter JH, Leonard JV and Halliday D 1990 In vivo enzyme activity in inborn errors of metabolism. Metabolism 39:799-807

24. Thompson, GN Francis DEM, Halliday D 1991 Acute illness in maple syrup urine disease: dynamics of protein metabolism and implications for management. J Pediatr 119:35-41

25. Hoerr RA, Matthews DE, Bier DM, Young VR 1991 Leucine kinetics from $\left[{ }^{2} \mathrm{H}_{3}\right]$ and $\left[{ }^{13} \mathrm{C}\right]$ leucine infused simultaneously by gut and vein. Am $\mathrm{J}$ Physiol 260:E111-E117

26. Duran M, Tielens AGM, Wadman SK, Stigter JCM, Kleijer WJ 1978 Effects of thiamine in a patient with a variant form of branched chain ketoaciduria. Acta Paediatr Scand 67:367-372

27. Chuang DT, Ku S, Cox RP 1982 Thiamin-responsive maple sugar urine disease: decreased affinity of the mutant branched-chain $\alpha$-keto acid dehydrogenase for $\alpha$-ketoisovalerate and thiamin pyrophosphate. Proc Natl Acad Sci USA 79:3300-3304

28. Elsas LJ, Danner DJ 1982 The role of thiamin in maple sugar urine disease. Ann NY Acad Sci 378:404-421

29. Danner DJ, Wheeler FB, Lemmon SK, Elsas LJ 1978 In vivo and in vitro response of human branched chain $\alpha$-ketoacid dehydrogenase to thiamine and thiamine pyrophosphate. Pediatr Res 12:235-238

30. Heffelfinger SC, Sewell ET, Elsas LJ, Danner DJ 1984 Direct physical evidence for stabilization of branched-chain $\alpha$-ketoacid dehydrogenase by thiamin pyrophosphate. Am J Hum Genet 36:802-807

31. Danner DJ, Davidson ED, Elsas LJ 1975 Thiamin increases the specific activity of human liver branched chain $\alpha$-ketoacid dehydrogenase. Nature 254:529530

32. Zhang B, Wappner RS, Brandt IK, Harris RA, Crabb DW 1990 Sequence of $\mathrm{E}_{1 \alpha}$ subunit of branched-chain $\alpha$-ketoacid dehydrogenase in two patients with thiamine-responsive maple syrup urine disease. Am $\mathrm{J}$ Hum Genet 46:843-846

33. Zhang B, Crabb DW, Harris RA 1988 Nucleotide and deduced amino acid sequence of the $\mathrm{E}_{1 \alpha}$ subunit of human liver branched-chain $\alpha$-ketoacid 
dehydrogenase. Gene 69:159-164

34. Nobukuni Y, Mitsubuchi H, Endo F, Alcaboshi I, Asaka J, Matsuda I 1990 Maple syrup urine disease: complete primary structure of the $\mathrm{E}_{1 \beta}$ sub-unit of human branched chain $\alpha$-ketoacid dehydrogenase complex deduced from the nucleotide sequence and a genetic analysis of patients with this disease. the nucleotide sequence

35. Danner DJ, Litwer S, Herring WJ, Pruckler J 1989 Construction and nucleotide sequence of a cDNA encoding the full-length preprotein for human branched chain acyltransferase. J Biol Chem 264:7742-7746

36. Litwer S, Herring WJ, Danner DJ 1989 Reversion of the maple syrup urine disease phenotype of impaired branched chain alpha-ketoacid dehydrogenase complex activity in fibroblasts from an affected child. $J$ Biol Chem 264:14597-14600

37. Chowdhury JR, Grossman M, Gupta S, Chowdhury NR, Baker Jr JR, Wilson JM 1991 Long-term improvement of hypercholesterolemia after ex vivo gene therapy in LDLR-deficient rabbits. Science 254:1802-1805

\section{Erratum}

There are several corrections to the article "Effect of Volume History on Measurements of Respiratory Mechanics Using the Interrupter Technique" by N. J. Freezer, T. Nicolai, and P. D. Sly (Pediatr Res 33:261266,1993 ). On page 262 in the second paragraph following the subheading "Interrupter Technique," the references cited as $(11,17)$ should actually be $(\mathbf{1 3}, \mathbf{1 8})$. In addition, the $y$ axis label for Figures 7 and 9 should be Rrs $\left(\mathrm{cmH}_{2} \mathrm{O} / \mathrm{ml} / \mathrm{s}\right)$, not Raw $\left.\left(\mathrm{cmH}_{2} \mathrm{O}\right) / \mathrm{ml} / \mathrm{s}\right)$. Dr. Freezer's new address for correspondence is Department of Thoracic Medicine, Royal Children's Hospital, Parkville, Australia 3052. The author regrets these errors. 